\title{
UPAYA PENINGKATAN HASIL BELAJAR BAHASA INGGRIS MELALUI PENERAPAN STRATEGI PEMAHAMAN BACAAN DIRECTED READING TINKING ACTIVITY (DRTA)
}

\author{
Efi Padrita ${ }^{1}$, Harun Sitompul ${ }^{2}$, R. Mursid ${ }^{2}$ \\ ${ }^{1}$ Sekolah Menengah Atas Swasta Cut Nyak Dhien, Langsa, Aceh \\ ${ }^{2,3}$ Program Pascasarjana, Universitas Negeri Medan, Medan \\ lefi_padrita@gmail.com; ${ }^{2}$ prof_runsit@yahoo.co.id $3 ;{ }^{3}$ mursid.tp@gmail.com
}

\begin{abstract}
Abstrak: Tujuan penelitian ini yaitu mengetahui: (1) keaktifan siswa selama proses pembelajaran pemahaman bacaan bahasa inggris dengan menggunakan strategi pembelajaran DRTA (DRTA); (2 peningkatan kemampuan pemahaman bacaan bahasa inggris dengan menerapkan strategi pembelajaran DRTA. Hasil penelitian menunjukkan bahwa: pembelajaran bahasa inggris diterapkan dengan strategi pembelajaran DRTA dan telah berhasil meningkatkan keaktifan siswa dalam belajar. Hal ini diketahui berdasarkan data observasi yang menunjukkan peningkatan keaktifan siswa selama siklus tindakan langsung. Pada siklus pertama terdapat 66,66 \% siswa yang aktif selama proses pembelajaran berlangsung. Selanjutnya jumlah ini meningkat pada siklus kedua menjadi 91,66 \% siswa yang aktif di kelas. Pembelajaran bahasa inggris dengan menerapkan strategi pemahaman bacaan DRTA dapat meningkatkan kemampuan memahami bacaan pada siswa. Berdasarkan pre test sebelum tindakan terdapat $36,11 \%$ siswa memiliki kemampuan memahami bacaan $\geq 70$. Setelah dilaksanakan tindakan maka terjadi peningkatan yaitu pada siklus pertama terdapat $61,11 \%$ siswa yang memperoleh nilai $\geq 70$. Namun karena persentase tersebut belum memenuhi indikator keberhasilan tindakan maka dilakukan siklus kedua. Setelah siklus kedua dilaksanakan maka terjadi peningkatan kemampuan memahami bacaan siswa menjadi $86,11 \%$ siswa yang memperoleh nilai $\geq 70$.
\end{abstract}

Kata Kunci: bahasa inggris, strategi pemahaman bacaan directed reading tinking activity

Abstract: The purpose of this study is to know: (1) the activeness of students during the learning process of English reading comprehension using DRTA learning strategies (DRTA); (2 improvement in English reading comprehension ability by applying DRTA learning strategies. The results of the study show that: English language learning is applied with DRTA learning strategies and has succeeded in increasing student activity in learning. This is known based on observation data which shows increased student activity during the action cycle Directly, in the first cycle there were $66.66 \%$ of students active during the learning process, then this number increased in the second cycle to $91.66 \%$ of students who were active in the class. Learning English by applying DRTA reading comprehension strategies could improve reading comprehension skills. Based on the pre-test before the action there were $36.11 \%$ of students had a reading ability of $\geq 70$. After the action was taken, an increase occurred in the first cycle, there were $61.11 \%$ of students who got a score of $\geq 70$. However, because the percentage was not meet the indicators of success of the action then the second cycle is carried out. After the second cycle was carried out, there was an increase in the ability to understand student reading to $86,11 \%$ of students who received a value of $\geq 70$.

Keywords: english, reading comprehension strategy directed reading tinking activity

\section{PENDAHULUAN}

Pesatnya

perkembangan ilmu pengetahuan dan teknologi di sisi lain juga menuntut masyarakat yang gemar membaca. Proses belajar yang efektif antara lain juga dilakukan melalui membaca. Dengan membaca, terutama buku yang memiliki arti yang penting bagi seorang individu, seseorang dapat memperoleh informasi dan pengetahuan sekaligus dapat mengembangkan daya imajinasi dan daya pikir dari informasi yang diperolehnya. Christopher Morley seorang penulis dari Amerika seperti yang dipaparkan Kompas dalam rubrik Ragam (2006:46) melukiskan hal ini dengan ilustrasi peristiwa ketika seseorang menjual sebuah buku kepada 
orang lain, orang tersebut tidak hanya menjual sebuah benda seberat 12 ons yang terdiri atas kertas, tinta, dan lem, tetapi berarti ia juga telah menjual sebuah hidup baru untuk sipembeli.

Bahasa inggris merupakan bahasa asing yang mendunia dan tetap akan diperlukan baik untuk dapat memahami teks berbahasa inggris di Perguruan Tinggi ditambah lagi untuk mencari kerja. Berdasarkan pengamatan British Institute seperti yang dikemukakan di liputan khusus Kompas 29 Agustus 2006, lulusan SMA di Indonesia saat ini tidak mampu lagi berkomunikasi dalam bahasa Inggris disebabkan pelajaran Bahasa Inggris di sekolah tidak lebih menekankan pada pengetahuan tentang bahasa inggris, bukan pada ketrampilan Bahasa Inggris. Mariam Kartikatresni, Business Manager The British Institute, selanjutnya berpendapat untuk menjadi asli dalam menggunakan bahasa, terutama belajar menggunakan Bahasa Inggris dibutuhkan ketrampilan praktis (ketrampilan berbahasa) yaitu mampu berbicara, dan mengungkapkan pendapat dan pikirannya. Seseorang dapat dinyatakan terampil berbahasa jika ia terampil dalam empat keterampilan, yaitu berbicara, mendengarkan, membaca dan menulis.

Menurut Wells (1987) dalam Peraturan Mendiknas no. 22 tahun 2006 tentang Standar isi untuk Satuan Pendidikan Dasar dan menengah, terdapat empat tingkat literasi sehubungan dengan standar kompetensi yang harus dimiliki siswa, antara lain : performative, functional, informational dan epistemic. Pada tingkat performative, si belajar mampu membaca dan menulis, dan berbicara simbol simbol yang digunakan ; pada tingkat functional, si belajar diharapkan dapat menggunakan bahasa untuk memenuhi kebutuha hidup sehari -hari seperti membaca bagian surat kabar yang diminati, membaca manual. Pada tingkat informational, si belajar diharapkan dapat mengakses pengetahuan dengan bahasanya sedangkan pada tingkat epistemic, si belajar diharapkan dapat mentransformasi pengetahuan dalam bahasa tertentu. Menurut peraturan Mendiknas no. 22 tentang Standar Isi untuk Satuan Pendidikan Dasar dan Menengah, mata pelajaran bahasa inggris di SMA/MA bertujuan agar peserta didik memiliki kemampuan sebagai berikut : (1) mengembangkan kompetensi berkomunikasi dalam bentuk lisan dan tulisan untuk mencapai tingkat literasi informational, (2) memiliki kesadaran tentang hakikat dan pentingnya bahasa inggris untuk meningkatkan daya saing bangsa dalam masyarakat global, (3) mengembangkan pemahaman peserta didik tentang keterkaitan antara bahasa dengan budaya.

Sehubungan dengan peranan bahasa inggris dalam penguasaan ilmu pengetahuan, penyelenggaraan pengajaran bahasa inggris, khususnya komponen membaca di tingkat SMA/MA, memiliki tujuan untuk membentuk siswa yang memiliki kemampuan memahami teks tulis berupa teks fungsional pendek (Pengumuman, label dan lain - lain) yang ditemukan dalam berbagai konteks situasi dan berbagai jenis teks (narative, deskriptif, recount, review, discussion, explanation, spoof dan lain - lain) yang menggunakan ragam bahasa tulis (Diknas, 2005:2). Untuk mencapai tujuan tersebut guru - guru bahasa inggris SMA/MA di kota Langsa masih menggunakan strategi pembelajaran mambaca yang relatif seragam. Hal ini dapat tergambar dari hasil wawancara yang dilakukan ke para peserta didik dan beberapa guru yang menggunakan strategi pembelajaran yang dimulai dengan siswa membaca tanpa tahu mangapa ia harus memahami teks tersebut dan mengapa informasi yang terdapat dalam satu teks penting untuk diketahui. Dengan kata lain siswa tidak menyadari manfaat yang diperolehnya dari wacana yang dibacanya. Minat dan semangat siswa untuk aktif menggali informasi yang terdapat dalam teks berfokus bukan pada tujuan tetapi kegiatan membaca yang dilakukan siswa praktis hanya disebabkan oleh intruksional oleh intruktur guru yang meminta siswanya membaca dan kemudian menggali informasi (memahami) teks tersebut.

Siswa mencoba menjawab pertanyaan berdasarkan teks yang diberikan. Jika terdapat gambar atau beberapa kata kunci, guru lebih cenderung mengabaikannya atau meminta siswa secara sambil lalu memperhatikan gambar yang ada atau mengartikan kata - kata kunci dengan mencarinya di kamus. Interaksi siswa sebagai pembaca dengan penulis teks berbahasa Inggris dengan beragam jenisnya praktis hanya sebatas kelas, meskipun dalam Kurikulum Berbasis Kompetensi pemusatan pengajaran pehamanan bacaan berkosentrasi pada pembiasaan berbagai jenis teks/bacaan sesuai dengan kultur penutur aslinya dengan cara memahami dan merespon makna teks fungsional pendek dalam konteks kehidupan sehari - hari, serta mengakses ilmu 
pengetahuan seyogyanya dilakukan pula di luar kelas.

Pada kenyataannya berdasarkan hasil observasi dan wawancara di lapangan, langkah - langkah guru dalam menyajikan materi tetap sama. Langkah - langkah guru dalam menyajikan materi tetap sama. Langkah langkah guru yang diupayakannya agar siswa mampu mencapai tujuan membaca teks, memahami informasi atau pesan teks relatif sama dengan upaya dan kiat yang telah dilaksanakan sebelum tujuan pembelajaran memahami teks berbahasa Inggris berfokus pada pemahaman teks dengan berbagai jenis/sruktur teks. Proses pemahaman bacaan berlangsung monoton dengan kegiatan menerjemahkan kata - kata sulit berdasarkan kamus atau informasi guru dan menjawab pertanyaan teks. Yang membedakan hanya pada kegiatan tambahan yang mengharuskan siswa mengidentifikasikan jenis teks berdasarkan generic strukture (struktur teks) masing masing teks. Tidak heran jika mereka nanti melanjutkan pendidikan di bangku kuliah mereka tidak mampu memenuhi tuntutan pembelajaran mata kuliah bahasa inggris yang menuntut mereka telah siap dengan ketrampilan membaca dan memahami buku - buku teks berbahasa Inggris yang berkaitan dengan bidang ilmu yang digelutinya.

\section{Hakikat Belajar dan Hasil Belajar \\ Pemahaman Bacaan Bahasa Inggris}

Pemahaman mengenai belajar dapat dinilai dari beberapa definisi yang telah dirumuskan oleh para ahli pendidikan yang didasarkan pada hasil analisa dan sudut pandang mengenai makna belajar. Menurut Sardiman (2009:20-21) dalam pengertian luas, belajar dapat diartikan sebagai kegiatan psikofisik menuju ke perkembangan pribadi seutuhnya. Kemudian dalam arti sempit, belajar dimaksudkan sebagai usaha penguasaan materi ilmu pengetahuan yang merupakan sebagian kegiatan menuju terbentuknya kepribadian seutuhnya. Dengan kata lain belajar pada hakikatnya merupakan usaha yang dilakukan untuk memenuhi pengetahuan yang bertujuan untuk membentuk kepribadian dan jati diri manusia.

Secara umum, menurut Sardiman (2009:22) belajar boleh dikatakan juga sebagai suatu proses interaksi antar diri manusia dengan lingkungannya yang mungkin terwujud pribadi, fakta, konsep ataupun teori. Dalam hal ini terkandung suatu maksud bahwa proses interaksi itu adalah :

a. Proses internalisasi dari sesuatu ke dalam diri yang belajar.

b. Dilakukan secara aktif, dengan segenap panca indera ikut berperan.

Pengertian belajar menurut teori kognitif adalah perubahan persepsi dan pemahaman yang tidak selalu berbentuk tingkah laku yang dapat diamati dan dapat diukur. Asumsi teori ini adalah bahwa setiap orang telah memiliki pengetahuan dan pengalaman telah tertata dalam bentuk struktur kognitif yang dimilikinya, Hamalik (2004:29). Belajar adalah suatu proses. Belajar bukan suatu tujuan tetapi merupakan suatu proses untuk mencapai tujuan. Jadi, belajar merupakan langkah - langkah atau prosedur yang ditempuh.menurut Hamalik belajar yang efektif sangat dipengaruhi oleh faktor - faktor kondisional yang ada, di antaranya : (a) faktor kegiatan, penggunaan dan ulangan ; siswa yang belajar banyak melakukan kegiatan baik kegiatan neural system, seperti melihat, mendengar, merasakan, berfikir. Kegiatan motoris, dan sebagainya maupun kegiatan kegiatan lainnya yang diperlukan untuk memperoleh pengetahuan, sikap, kebiasaan dan minat. Apa yang telah dipelajari perlu digunakan secara praktis dan diadakan ulangan secara kontinu di bawah kondisi yang serasi, sehingga penguasaan hasil belajar menjadi lebih mantap, (b) belajar memerlukan latihan, dengan jalan : relearning, recalling, dan reviewing agar pelajaran yang terlupakan dapat dikuasai kembali, dan pelajaran yang belum dikuasai akan dapat lebih mudah dipahami, (c) belajar siswa lebih berhasil, belajar akan lebih berhasil jika siswa merasa berhasil dan mendapatkan kepuasannya, (d) siswa yang belajar perlu mengetahui apakah ia berhasil atau gagal dalam belajarnya, (e) faktor asosiasi besar manfaatnya dalam belajar, karena semua pengalaman belajar antara yang lama dan yang baru secara berurutan diasosiasikan sehingga menjadi satu kesatuan pengalaman, (f) pengalaman masa lampau (bahan apersepsi) dan pengertian pengertian yang telah dimiliki oleh siswa, besar perannya dalam proses belajar, pengalaman dan pengertian itu menjadi dasar untuk menerima pengalaman - pengalaman baru dan pengertian - pengertian baru, (g) faktor kesiapan belajar. Murid yang telah siap belajar akan dapat melakukan kegiatan belajar lebih mudah dan lebih berhasil, (h) faktor minat dan usaha. 
Belajar dengan minat akan mendorong siswa belajar lebih baik dari pada belajar tanpa minat, (i) faktor - faktor fisiologis. Kondisi badan siswa yang belajar sangat berpengaruh dalam proses belajar, (i) faktor intelegensia. Murid yang cerdas akan lebih berhasil dalam kegiatan belajar karena ia akan lebih mudah menangkap dan memahami pelajaran.

Berkenaaan dengan defenisi belajar secara normal, Gagne dan Briggs (1979:43) dalam Gredler (1994:187) mendefenisikannya sebagai seperangkat proses kognitif yang mengubah sifat stimulasi dari lingkungan menjadi beberapa tahapan pengolahan informasi yang diperlukan untuk memperoleh kapabilitas yang baru. Belajar terjadi ketika seseorang memperoleh kemampuan tertentu untuk melakukan sesuatu. Kemampuannya tidak dapat diamati, hanya dapat terlihat dari perilaku si belajar dalam unjuk kerja, dengan demikian barulah dapat disimpulkan bahwa si belajar telah memiliki kemampuan yang telah dipelajarinya. Kejadian internal yang dialami oleh seseorang dalam proses belajarnya dijelaskan dalam rangkaian sembilan fase oleh Gagne (1988:246) ; Driscoll (1994 :351) yang dimulai dengan perhatian (reception, gaining attention, alertness), si belajar khusus memperhatikan hal yang akan dipelajari. Fase kedua menyadari tujuan belajar (motivation, expectancy, si belajar sadar akan tujuan intruksional dan bersedia melibatkan diri. Fase ke tiga menggali (retrieval to working memory), si belajar mengingat kembali dari ingatan jangka panjang apa yang sudah diketahui/dipahami/dikuasai tentang apa yang sedang dipelajari. Fase ke empat berpresepsi selektif (selective perception), si belajar mengamati unsur - unsur dalam perangsang yang relevan dengan apa yang sedang dipelajari. Fase ke lima mengolah informasi (enconing, entry to storage), si belajar memberikan makna pada pola perseptual dengan membuat informasi yang bermakna dengan menghubungkan informasi lama yang digali dari ingatan jangka panjang. Fase ke enam, menggali informasi (responding to question or task), si belajar membuktikan melalui suatu prestasi atau unjuk kerja kepada guru dan dirinya sendiri bahwa apa yang dipelajarinya telah dikuasai. Fase ketujuh, mendapatkan umpan balik (feedback, reinforcement), si belajar mendapat penguatan dari guru kalau prestasi atau unjuk kerjanya tepat, dan mendapat koreksi kalau prestasi atau unjuk kerjanya salah. Fase ke delapan, penilaian kemampuan (assessing performance) pengetahuan baru sebagai respon sebaiknya dapat ditampilkan si belajar perunit atau perbab. Fase terakhir, memantapkan hasil belajar (frequent retrieval tranfer), si belajar mengerjakan berbagai tugas untuk mengakarkan hasil belajar, si belajar mengadakan transfer belajar, siswa mengulang - ngulang kembali.

Selanjutnya Gagne dalam Soekamto (1997:30) memiliki pandangan yang sedikit berbeda bahwa belajar merupakan sesuatu yang terjadi secara alamiah, tetapi hanya akan terjadi dengan adanya kondisi - kondisi tertentu, yaitu kondisi internal dan eksternal. Kondisi internal menyangkut kesiapan si belajar dan apa yang telah dipelajari sebelumnya, sedangkan kondisi eksternal merupakan situasi belajar dan penyajian stimulasi yang secara sengaja diatur oleh guru dengan tujuan memperlancar proses belajar.

Pakar teknologi pendidikan, Gagne, Briggs dan Wager (1993: 11) dalam Prawiradilaga (2007: 24) menyempurnakan pandangan ini dengan menyatakan bahwa proses belajar seseorang dapat dipengaruhi oleh faktor internal peserta didik itu sendiri dan faktor eksternal, yaitu pengaturan kondisi belajar. Proses belajar terjadi karena sinergi memori jangka pendek dan jangka panjang diaktifkan melalui penciptaan faktor eksternal, yaitu pembelajaran atau lingkungan belajar. Melalui inderanya, si belajar dapat menyerap materi secara.

Molenda (2005: 17) lebih cenderung menyimpulkan hasil belajar bergantung pada seberapa baik metode pembelajaran direncanakan dan dimplementasikan. Joyce dan Weil (1996:142) lebih berfokus pada bagaimana setelah terjadi proses belajar dapat terjadi pula peningkatan komitmen dan rasa mawas diri seseorang melalui belajar berfikir dan menganalisa perkembangan sosial si belajar. Jika berfokus pada pembelajaran bahasa asing khususnya pembelajaran di dalam kelas, Allwright dan Bailey (1991: 23) berpendapat bahwa ada tiga hasil belajar yang disebutkan input, practise opportunities, dan receptivity. Input atau masukan berupa informasi yang dapat dipahami, interaksi dan kebudayaan si belajar Practise Opportunities, kesempatan untuk mempraktekkan apapun yang sedang diusahakannya untuk dipelajari. Apapun yang direncanakan oleh guru untuk membangun 
suasana kondusif di dalam kelas dapat menghasilkan kesediaan memerima berupa sikap yang aktif dan terbuka dan adanya keinginan untuk menerima bahasa dan budaya yang sedang dipelajarinya (Allwright Bailey 1991: 1135).

Hasil belajar siswa di sisi lain merupakan perolehan (prestasi) yang dicapai secara maksimal oleh siswa. Jika belajar merupakan proses atau kegiatan yang dijalani secara sadar untuk mendapatkan perubahan, baik dalam bentuk pengetahuan, ketrampilan ataupun sikap, maka hasil belajar merupakan prestasi yang dicapai siswa berkat adanya usaha sadar untuk mendapat perubahan, baik dalam pengetahuan, ketrampilan dan sikap tersebut. Prestasi tersebut selanjutnya merupakan kesanggupan untuk berbuat sesuatu sesuai dengan pengetahuan, pengalaman, dan ketrampilan yang telah mereka miliki. Dengan demikian, semakin banyak perolehan (prestasi) yang dimilikinya, semakin tinggi pula tingkat kesanggupan untuk berbuat masa berikutnya.

Ruang lingkup mata pelajaran Bahasa Inggris di SMA/MA meliputi: (1) kemampuan berwacana, yakni kemampuan memahami dan/atau menghasilkan teks lisan dan/atau tulisan yang direalisasikan dalam empat keterampilan berbahasa, yaitu mendengarkan, berbicara, membaca dan menulis secara terpadu untuk mencapai tingkat literasi informational, (2) kemampuan memahami dan menciptakan berbagai teks fungsional pendek dan monolog serta essai berbentuk Procedure, descriptive, recount, narrative, report, news item, analytical exposition, spoof, explanation, discussion, review, public speaking. Gradasi bahan ajar tampak dalam penggunaan kosa kata, tata bahasa, dan langkah - langkah retorika, (3) kompetensi pendukung, yakni kompetensi linguistik (menggunakan tata bahasa dan kosa kata, tata bunyi, tata tulis), kompetensi sosiokultural (menggunakan ungkapan dan tindak bahasa secara berterima dalam berbagai konteks komunikasi), kompetensi strategi (mengatasi masalah yang timbul dalam proses komunikasi dengan berbagai cara agar komunikasi tetap berlangsung), dan kompetensi pembentuk wacana (menggunakan piranti pembentuk wacana).

\section{Hakikat Aktivitas Belajar}

Menurut Poerwadarminta (2003: 23) bahwa aktivitas adalah kegiatan. Jadi aktivitas belajar adalah kegiatan-kegiatan siswa yang menunjang keberhasilan belajar. Dalam hal kegiatan belajar, Rousseau (dalam Sadirman, 2010:96) memberikan penjelasan bahwa segala pengetahuan itu harus diperoleh dengan pengamatan sendiri, penyelidikan sendiri, dengan bekerja sendiri baik secara rohani maupun teknis Tampa adanya aktivitas, proses belajar tidak akan mungkin terjadi.

Belajar bukanlah proses belajar kehampaan, dan tidak pula pernah sepi dari proses aktivitas. Tidak pernah melihat orang belajar tampa melibatkan aktivitas raganya. Apabila aktivitas belajar itu berhubungan dengan masalah belajar menulis, mencatat, memandang, membaca, mengingat, berfikir, latihan atau praktek dan sebagainya.

Dari beberapa pendapat di atas, dapat disimpulkan bahwa aktivitas dalam proses suatu pembelajaran merupakan asas yang terpenting, karena belajar sendiri merupakan suatu kegiatan maka tidak mungkin seseorang belajar. Tidak hanya berupa aktivitas fisik saja tetapi juga aktivitas psikis. Aktivitas fisik adalah kegiatan yang dilakukan dengan gerakan anggota badan seperti membuat sesuatu, bermain ataupun bekerja, tidak hanya duduk, berbicara, mendengarkan, dan melihat. Sedangkan aktivitas psikis adalah kegiatan yang melibatkan daya jiwa, pikiran, dan emosi dalam proses pembelajaran.

\section{Hakikat Strategi Pembelajaran Pemahaman Bacaan.}

Miarso (2004:530) mengatakan strategi pembelajaran adalah pendekatan menyeluruh pembelajaran dalam suatu sistem pembelajaran, yang berupa pedoman umum dan kerangka kegiatan untuk mencapai tujuan umum pembelajaran, yang dijabarkan dari pandangan falsafah dan atau teori belajar tertentu. Miarso (2004) mendukung pendapat Romizowski (1981) yang membagi dan strategi dasar berdasarkan pandangan strategi pembelajaran sebagai suatu pendekatan menyeluruh, yaitu ekspositori (penjelasan) dan discovery (penemuan).

Senada dengan Miarso (2004), Gulo (2005: 12) menyatakan strategi belajar mengajar adalah rencana dan cara - cara membawakan pengajaran agar segala prinsip dasar dapat terlaksana dan segala tujuan pengajaran dapat dipakai secara efektif, Strategi belajar mengajar yang membelajarkan dan peserta didik dan mengharapkan peserta didik dapat memproses sendiri penemuannya melalui 
stimulasi dan pengarahan dari guru serta dilihat dari cara memproses penemuan, terbagi dua, ekspositori dan Strategi discovery. Menurutnya, strategi dapat digolongkan dalam dua kutub yang ekstrem. Satu sisis siswa terlbat secara maksimal dalam usaha mencapai dan menemukan, strategi ini disebut strategi inkuiri dan discovery, sedangkan pada sisi yang lain strategi yang disebut strategi ekspositori, keterlibatan siswa sangat terbatas pada menerima informasi. Dick, Carey dan Carey (2005) menyatakan bahwa strategi pembelajaran menjelaskan komponen komponen umum dari seperangkat bahan pembelajaran dan prosedur yang akan digunakan dalam mengelola dalam mengelola kegiatan pembelajaran untuk menghasilkan hasil belajar tertentu. Strategi pembelajaran bukanlah sekedar penjelasan sederhana berkenaan dengan materi yang akan di sampaikan kepada siswa. Menurut Suparman (1912: 25) strategi pembelajaran berkenaan dengan pendekatan pengajaran dalam mengelola kegiatan pembelajaran untuk menyampaikan materi secara sistematik, sehingga tercapai kemampuan yang diharapkan. Strategi pembelajaran mengandung empat unsur, yaitu : (1) urutan kegiatan pembelajaran, yaitu kegiatan pengajar dalam menyampaikan isi pelajaran kepada siswa (2) metode pembelajaran, yaitu cara mengajar mengorganisasikan materi pelajaran agar terjadi proses belajar secara efektif dan efisien, (3) media pembelajaran yaitu peralatan dan bahan pembelajaran yang digunakan pengajar dan siswa dalam kegiatan pembelajaran, (4) waktu yang digunakan pengajar dan siswa dalam menyelesaikan setiap langkah dalam tiap pembelajaran.

Kamus pendidikan yang dikomplikasi oleh Cooper (2004: 135) mendefinisikan strategi pembelajaran sebagai sebuah metode pembelajaran yang di dasari oleh pengajaran dan strategi kognitif dalam rangka mencapai penyelesaian tuga yang berhasil. G.Ellis dan Sinclair (1989) dalam Nunan (1991:169) mengkatagorikan strategi berdasarkan pemusatan keterampilan makro; listening (mendengarkan), Speaking (berbicara), reading (membaca), atau writing (menulis). Kesemuannya membutuhkan pemahaman termasuk di dalamnya vocabulary (pembendaharaan kosa kata) dan grammar (tata bahasa).
Skimming dan scanning menurut Grellet (1981) seperti yang disitasi oleh Omaggio (1986: 151) adalah cara - cara seseorang membaca, pada saat skimming si pembaca menggerakkan matanya melewati kalimat demi kalimat yang terdapat dalam teks yang dibacanya dan pada saat bersamaan mengambil kesimpulan dari isi teks tersebut. Jika pembaca secara cepat mencari beberapa potongan informasi penting yang terdapat dalam teks yang dibacanya maka si pembaca menggunakan cara yang disebutkan dengan scanning.

Jika menurut Grellet skimming dan scanning merupakan cara membaca, bagi Soedarso (2004: 88) merupakan keterampilan membaca yang diatur secara sistematis untuk mendapatkan hasil yang efisien. Kedua keterampilan ini dianggapnya jurus membaca yang sangat ampuh untuk mengatur kecepatan dalam membaca dan sangat efektif dalam memberikan hasil. Bacaan apa saja baik itu buku, majalah, ataupun surat kabar harus dibaca sesuai dengan tujuan si pembaca. Skimming bertujuan mendapatkan informasi sebayak banyaknya, gerakan mata hampir seperti membaca lengkap, kecuali jika harus melompati bagian - bagian tertentu. Skimming bukan hanya sekedar menyapu jalaman, tetapi lebih merupakan keterampilan membaca yang diatur secara sistematis untuk mendapatkan hasil yang efisien untuk berbagai tujuan, antara lain : mengenali topik bacaan, mengetahui pendapat atau opini orang lain, mendapatkan bagian penting yang di perlukan tanpa membaca seluruhnya, mengetahui organisasi penulisan, urutan ide pokok dan untuk memilih bahan yang perlu dipelajari dan diingat.

Strategi membaca terbagi atas 4 model strategi membaca, strategi bottom-up (bawahatas), top-down (atas -bawah), electic (campuran), ataupun interaktif didukung pula oleh Nunan (1991:67) yang memaparkan bahwa apapun model strategi yang dikembangkan oleh para ahli tetap berdasarkan dan melibatkan strategi bottom-up dan top-down. Kedua strategi ini juga merupakan bagian dari pemerosesan informasi. Strategi to-down menggunakan pengetahuan sebelumnya (higher lever knowledge) dalam menganalisa dan memproses informasi yang diterima. Sebaliknya strategi bottom-up menggunakan informasi pokok yang telah ada dalam data.

Strategi diperlukan untuk mencapai hasil belajar yang optimal. Menurut Maisah dan 
Yamin (2009: 220) penilaian dilakukan untuk menentukan apakah peserta didik telah berhasil menguasai suatu kompetensi yang mengacu pada indikator atau tidak. Penilaian dilakukan pada waktu pembelajaran atau setelah pembelajaran berlangsung. Sebuah indikator dapat dijaring dengan beberapa soal/tugas. Penilaian yang dimaksud dapat ditentukan dalam bentuk angka - angka atau nilai yang diberikan kepada siswa setelah menjalani proses pembelajaran. Biasanya diukur dengan menggunakan tes formatif atau tes sumatif.

Strategi yang dapat digunakan untuk meningkatkan pembelajaran ada banyak antara lain kontruktivisme, elaborasi, KWL, DRTA da lain sebagainya. Namun yang diamati pada penelitian ini adalah hanya strategi Directed Reading Thinking Activity.

\section{Strategi Pembelajaran Pemahaman Bacaan Directed Reading Thinking Activity.}

Jika memahami bacaan, seorang guru dituntut untuk mendesain kegiatan - kegiatan pemahaman yang berhubungan dengan seluruh tujuan dan proses yang terjadi dalam kegiatan membaca. Dengan mendesain kegiatan tersebut, guru mendesain berbagai macam bentuk kegiatan membaca berdasarkan jenis teks yang sedang dibaca dan tujuan mengapa teks tersebut dibaca (Omaggio, 1986: 153).

Pada model strategi interaktif, teks bacaan hanya menyediakan arahan bagi pembaca, pembaca menemukan dan membangun sendiri makna teks berdasarkan pengetahuan awal si pembaca. Model ini menekankan arti penting latar belakang pengetahuan pembaca dan struktur pengetahuan awal si belajar sebagai pembaca. Strategi yang dikembangkan oleh Nopak dan Gowin (1984) dalam Oxford (1990: 241) dianggap sangat bermanfaat dalam kegiatan Pre-reading untuk memahami teks bacaan. Memanfaatkan struktur pengetahuan awal dengan cara memperluas jaringan kata atau konsep dapat membantu siswa membuat hubungan yang penting dan memperkaya situasi komunikasi secara konstektual.

Pendekatan klasik dalam mengajar membaca dengan tujuan mengembangkan kompetensi siswa adalah dengan bertanya. Bertanya disini bukanlah bertanya yang dimaksudkan untuk menguji tetapi lebih kepada menggunakan sejumlah pertanyaan yang dimaksudkan untuk membantu siswa mengembangkan pemahaman mereka mengenai berbagai teks. Pendekatan lain yang harus diingat oleh guru adalah pemilihan jenis teks yang tepat, tidak terlalu sulit baik bentuk tata bahasannya, atau materi yang sangat teknis yang nantinya akan melahirkan rasa frustasi pada siswa. Pendekatan berikutnya adalah seluruh aspek membaca, seluruh jenis hubungan, baik antara kata dengan kata dalam sebuah teks, antara pengarang dengan pembaca, dan antara pembaca dengan teks, serta antara teks dengan budaya (makna secara antropologi). Pendekatan keempat adalah jenis pertanyaan yang memudahkan atau mempersulit siswa (Brought et.al.1978:89).

Strategi DRTA dikembangkan oleh Stauffer (dalam Rahim, 2005: 47) yang diarahkan untuk mencapai tujuan umum dan memfokuskan keterlibatan siswa dengan teks melalui kegiatan memprediksi dan membuktikan prediksinya disaat mereka membaca. Guru mengamati siswanya ketika mereka membaca, dalam rangka mendiagnosis kesulitan dan menawarkan bantuan ketika siswa sulit berinteraksi dengan bahan bacaan.

Memprediksi tentang apa yang akan terjadi dalam suatu teks mendorong siswa berpikir tentang peran teks. Dalam membuat prediksi siswa menggunakan latar belakang pengetahuan atau struktur pengetahuan awal tentang topik dan pengetahuan mereka tentang pola organisasi teks, mencoba mengkonfirmasikan satu atau lebih prediksi dari siswa lain dalam kelompok untuk mengkonfirmasikan atau menolak gagasannya sendiri. Strategi yang dikembangkan oleh Novak dan Gowin 1984 dalam Oxford (1990: 91) menegaskan sangat penting bagi siswa sekolah menengah atas memprediksi dengan menebak secara cerdas karena dapat membuat mereka melepas kebiasaan harus mengenal dan memahami setiap kata yang tidak dapat mereka pahami artinya. Menebak arti dapat dilakukan siswa dengan mengaitkan petunjuk berupa bentuk teks bacaan seperti pendahuluan, ringkasan, simpulan, judul atau cara pembagian teks bacaan. Menebak dapat pula dilakukan selalui melalui gambar atau tabel, melalui deskripsi tentang tokoh yang terdapat dalam teks bacaan. Jika seorang tokoh dideskripsikan penulis dengan kata 'sinister' (seram) atau 'mean' (kejam) siswa sebagai penerima pesan dapat menebak sisa informasi yang disampaikan penulis tentunya sang tokoh akan bertingkah laku tertentu terkait dengan kata sinister dan mean tadi tanpa harus 
menterjemahkan seluruh arti kata yang ada dalam teks. Selanjutnya Novak dan Gowin dalam Oxford (1990) menambahkan bahwa latar belakang siswa berupa pengetahuan mengenai bahasa target yang sedang dipelajarinya, topik yang sedang dibacanya, dan pengetahuan umum tentang topik terkait, baik tentang seni, politik, ataupun kesustraaan amat sangat membantu siswa dalam memahami teks yang dibacanya.

Mengetahui tujuan melakukan sesuatu membuat siswa menempatkan energi mereka di saluran dan arah yang tepat. Guru dapat membantu dengan membiarkan siswa belajar sebelum mengerjakan tugas tersebut. Menurut Hyland (1993: 109) tujuan membaca teks bacaan tertentu adalah hal yang terpenting untuk menentukan strategi membaca. Keikutsertaan emosional dapat dibangun dengan memaparkan tujuan dan mengetahui manfaat materi yang sedang dipelajari. Tanpa keikutsertaan emosional tidak akan ada belajar. De Porter dan rekan - rekannya (2003: 202) dalam bukunya Quantum Teaching menyatakan dengan menyatakan tujuan, komunikasi antara siswa dan guru akan terjalin baik. Pada kegiatan membaca siswa dapat mencari tujuannya membaca dengan mempelajarinya situasi dan jenis teks yang dibacanya.

Pada saat siswa memprediksi siswa dituntut untuk berfikir, siswa dibimbing untuk menemukan sendiri konsep yang harus dikuasainya melalui proses dialogis yang terus menerus dengan memanfaatkan pengalaman siswa. Langkah kegiatan pembelajaran ini jika mengacu pada pendapat Joyce dan Weil (1980) merupakan strategi yang dapat mengembangkan kemampuan berpikir dengan memanfaatkan pengalaman siswa sebagai titik tolak berpikir. Yang Hakikat dari strategi ini adalah kemampuan berfikir seseorang sudah pasti diikuti oleh kemampuan mengingat dan memahami. Jika mengingat hanya melibatkan usaha penyimpanan informasi atau sesuatu yang telah dialami dan akan keluar disaat dibutuhkan. Memahami lebih membutuhkan perolehan apa yang didengar dan dibaca serta melihat keterkaitan antara aspek - aspek dalam memori. Untuk memiliki kemampuan mengingat dan memahami dibutuhkan kemampuan berfikir. Kemampuan berfikir tudak mungkin terjadi tanpa adanya memori, bila seseorang kurang memiliki daya ingat (working memory) maka orang tersebut tidak mungkin sanggup menyimpan masalah dan informasi yang cukup lama. Jika seseorang kurang memiliki daya ingat jangka panjang (long term memory) maka orang tersebut dipastikan memiliki catatan masa lalu yang dapat digunakan untuk memecahkan masalah masalah yang dihadapi pada masa sekarang.

Menurut Piaget seperti yang diatasi oleh Budiningsih (2005: 39), salah satu tahap perkembangan anak menurut kognitifnya adalah tahap oprasional formal (umur 11/12-18 tahun ) dimana periode ini setingkat usia siswa sekolah menengah. Ciri pokok perkembangan pada tahap ini adalah anak sudah mampu berfikir abstrak dan logis dengan menggunakan pola pikir "Kemungkinan atau membuat prediksi". Model berfikir ilmiah dengan tipe hipotetica deductive dan inductive sudah mulai dimiliki anak, dengan kemampuan menarik kesimpulan, menafsirkan dan mengembangkan hipotesa. Pada tahap ini kondisi berfikir anak sudah dapat : (1) bekerja secara efektif dan sistematis, (2) menganalisis secara kombinasi. Dengan demikian telah diberikan dua kemungkinan penyebabnya, misalnya $\mathrm{C} 1$ (mengingat) dan $\mathrm{C} 2$ (memahami) menghasilkan $\mathrm{R}$ (response), anak dapat merumuskan beberapa kemungkinan, (3) berpikir secara proporsional, yakni menentukan macam - macam proporsional tentang C1, C2 dan $\mathrm{R}$ misalnya, (4) menarik generasilisasi secara mendasar pada satu macam ini. Pada tahap ini mula - mula Piaget percaya bahwa sebagian remaja mencapai formal operations paling lambat pada usia 15 tahun. Tetapi berdasarkan penelitian maupun studi selanjutnya menemukan bahwa banyak siswa bahkan mahasiswa walaupun usiannya telah melampaui, belum dapat melakukan formal operations.

Adapun tujuan strategi DRTA secara lebih rinci adalah sebagai berikut: (1) mendorong siswa untuk menjadi pembaca aktif dan berpikir, (2) merangsang atau mengaktifkan pengetahuan siswa (3) mengajak siswa memonitor pemahaman mereka atas bacaan yang mereka baca, (4) membantu menguatkan kemampuan membaca dan ketrampilan berpikir kritis siswa. Strategi DRTA dapat digunakan sebelum membaca, selama membaca dan setelah membaca. DRTA dapat digunakan secara individu, kelompok kecil dan keseluruhan kelas yang sudah diatur.

Adapun prosedur dari DRTA adalah sebagai berikut: 
$\mathrm{D}$ (directed $)=$ Langsung. Guru secara langsung mengaktifkan siswa berpikir lainnya.guru harus menggunakan pertanyaan - pertanyaan terbuka untuk siswa secara langsung, agar mereka membuat prediksi tentang isi atau perspektif dari Siswateks (misalnya,"Dengan melihat judul ini, apa yang anda pikirkan?")

$\mathrm{R}$ (reading) = Membaca. Siswa membaca sampai poin yang telah ditentukan untuk berhenti. Guru kemudian meminta siswa dengan pertanyaan - pertanyaan tentang informasi dan meminta mereka untuk mengevaluasi prediksi mereka dan memperbaikinya jika diperlukan. Proses ini harus dilanjutkan sampai siswa telah membaca setiap bagian dari teks tersebut dan berfikir.

$\mathrm{T}$ (thinking) = Berfikir. Pada akhir setiap bagian, siswa kembali melihat teks yang ada dan berfikir tentang prediksi mereka. Siswa harus memverifikasi atau memodifikasi prediksi mereka dengan menemukan pertanyaan - pertanyaan pendukung dalam teks. Guru menanyakan hal - hal berikut : (a) apa pendapat anda tentang prediksi Anda sekarang ?, (b) apa yang anda temukan dalam teks untuk membuktikan prediksi anda?, (c) apa yang anda baca dalam teks yang membuat anda mengubah prediksi anda?

A (activity) $=$ Kegiatan. Kegiatan disini maksudnya adalah kegiatan atau aktivitas membaca, yang mana selama kegiatan pemahaman bacaan tersebut siswa langsung aktif dan guru sebagai fasilitator serta guru mitra sebagai pemantau kegiatan dan memperhatikan hasil belajar. Jika hasil belajarnya maksimal itu yang diharapkan tetapi jika tidak maka kegiatan tersebut bisa diulang kembali.

Strategi ini bukan hanya sekedar model pembelajaran yang diarahkan agar peserta didik dapat mengingat dan memahami berbagai data, fakta atau konsep tersebut dapat dijadikan sebagai alat untuk melatih kemampuan dan berfikir siswa dalam menghadapi dan memecahkan persoalan. (Sanjaya, 2006 : 223). Landasan psikologis strategi ini adalah aliran kognitif yang memandang hakekat belajar adalah peristiwa mental behavioral. Peristiwa mental merupakan perilaku manusia tidak semata - mata gerak fisik tetapi juga yang lebih penting adalah faktor pendorong yang menggerakkan fisik itu. Hal itu mengacu pada apa yang dikemukakan oleh Piaget " ... children have a bulit-indesire to learn". Manusia selamanya memiliki kebutuhan untuk belajar dan kebutuhan itulah yang mendorong manusia untuk perilaku.

Berdasarkan latar belakang, identifikasi masalah, pembatasan masalah, maka dapat dirumuskan masalah dalam penelitian ini sebagai berikut: (1) Apakah dengan penerapan strategi pembelajaran DRTA dapat meningkatkan aktivitas siswa selama proses pembelajaran pemahaman bacaan bahasa inggris ?; (2) Apakah dengan penerapan strategi pembelajaran DRTA dapat meningkatkan kemampuan pemahaman bacaan bahasa Inggris?.

\section{METODE}

Penelitian ini dilaksanakan pada siswa kelas XI IPA di SMAS Cut Nyak Dhien Langsa Jalan A. Yani Langsa. Karena peneliti menemukan kesenjangan masalah belajar pada kelas dan sekolah tersebut. Penelitian ini merupakan penelitian tindakan kelas yang dilaksanakan melalui dua siklus untuk melihat dan memperbaiki pembelajaran bahasa Inggris melalui penerapan strategi Strategi pemahaman bacaan atau Directed Reading Thinking Activity. Adapun yang dijadikan subjek penelitian ini adalah siswa kelas XI IPA 1 yang terdiri dari 36 siswa dengan komposisi 17 laki laki dan 19 perempuan dan 1 orang guru mitra sebagai Observer.

PTK secara prosedurnya adalah dilaksanakan secara partisipatif atau kolaborasi antara guru dan peneliti, dimulai dari tahap orientasi dilanjutkan rencana tindakan yang dilakukan dengan pelaksanaan tindakan dalam siklus pertama. Kemudian diskusi - diskusi yang bersifat analitik yang kemudian dilanjutkan kepada langkah refleksi evaluative atas kegiatan yang telah dilakukan pada siklus pertama, dan selanjutnya mempersiapkan rencana modifikasi, koreksi atau penyempurnaan pada siklus kedua dan seterusnya (Iskandar, 2009: 66-67).

Dalam Penelitian Tindakan Kelas ini peneliti sebagai perancang pembelajaran berkolaborasi dengan rekan guru bahasa inggris sebagai observer (mitra penelitian) yang akan melaksanakan rancangan pembelajaran di dalam kelas. penerapan rencana tindakan berdasarkan permasalahan yang ada, kemungkinan pemecahan masalahnya, implementasinya di lapangan sampai pada tahap evaluasi dan perumusan tindakan berikutnya. Proses penelitian tindakan ini akan dilaksanakan dalam rangkaian siklus, dan setiap 
Jurnal Teknologi Pendidikan, Vol. 11, No. 2, Oktober 2018, p-ISSN; 1979-6692, e-ISSN: 2407-7437

siklus akan dilaksanakan sesuai dengan perubahan yang ingin dicapai.

\section{Tabel 1. Prosedur Penelitian}

\begin{tabular}{|c|c|c|c|}
\hline Tahapan & & Uraian/Kegiatan & Output \\
\hline Perencanaan & $\begin{array}{l}4) \\
5) \\
6)\end{array}$ & $\begin{array}{l}\text { Peneliti bersama guru mitra melakukan analisis } \\
\text { kurikulum bahasa inggris untuk mengetahui kompetensi } \\
\text { dasar pada proses pembelajarannya yang akan } \\
\text { menggunakan strategi DRTA. } \\
\text { Membuat rencana pembelajaran dengan menerapkan } \\
\text { strategi pembelajaran DRTA. } \\
\text { Merancang skenario pembelajaran dengan menggunakan } \\
\text { strategi DTRA. } \\
\text { Membuat Intrumen yang digunakan dalam siklus PTK. } \\
\text { Menyusun alat evaluasi pembelajaran. } \\
\text { Menerapkan indikator ketercapaian dan menyusun } \\
\text { intrument pengumpulan data }\end{array}$ & $\begin{array}{l}\text { - Skenario pembelajaran } \\
\text { dan instrument. } \\
\text { - Perangkat RPP } \\
\text { - Perangkat Skenario } \\
\text { - Alat Peraga } \\
\text { - Tes } \\
\text { - Non - Tes }\end{array}$ \\
\hline Tindakan & 1) & $\begin{array}{l}\text { Hasil Analisis Kurikulum yang telah dilakukan } \\
\text { selanjutnya diimplementasikan dengan menjelaskan pada } \\
\text { siswa mengenai konsep strategi DRTA. } \\
\text { Mendeskripsikan materi pelajaran dengan skenario } \\
\text { strategi DRTA yang telah dirancang. } \\
\text { Didasarkan pada jumlah siswa sebanyak } 42 \text { orang maka } \\
\text { guru membagi menjadi } 8 \text { kelompok dengan perincian } \\
\text { kelompok } 1 \text { sampai } 6 \text { terdiri dari } 5 \text { orang dan kelompok } 7 \\
\text { dan } 8 \text { terdiri dari } 6 \text { orang. } \\
\text { Setiap kelompok menyebutkan prediksi judul/gambar } \\
\text { dari bacaan yang telah dipersiapkan oleh guru dan } \\
\text { peneliti. } \\
\text { Setiap kelompok menyebutkan prediksi hasil diskusi } \\
\text { mereka berdasarkan judul/gambar bacaan yang diberikan } \\
\text { oleh guru dan peneliti. } \\
\text { Materi pelajaran disampaikan dengan menggunakan } \\
\text { skenario yang telah dirancang. } \\
\text { Siswa diberi kesempatan untuk membaca dan memahami } \\
\text { bacaan yang telah disediakan sambil menyesuaikan } \\
\text { apakah prediksi yang mereka sebutkan sesuai ataupun } \\
\text { mendekati dengan judul/gambar yang telah mereka } \\
\text { prediksi sebelumnya. Siswa disuruh membaca bacaan } \\
\text { kembali sambil menjawab pertanyaan bacaan serta } \\
\text { menentukan jenis teks (genre of the text) dan tujuan teks } \\
\text { tersebut. } \\
\text { Guru dan siswa bersama - sama mendiskusikan hasil } \\
\text { pekerjaan mereka dengan jawaban yang benar serta } \\
\text { membuat kesimpulan terhadap materi yang telah } \\
\text { disajikan dengan srategi DRTA. } \\
\text { Diakhir tindakan, guru memberikan kuis yang berkaitan } \\
\text { dengan materi yang telah diberikan. }\end{array}$ & $\begin{array}{l}\text { - Hasil awal kemampuan } \\
\text { siswa. } \\
\text { - Siswa dapat memahami } \\
\text { bacaan dengan } \\
\text { menggunakan strategi } \\
\text { belajar yang diterapkan } \\
\text { - Membagi siswa dalam } \\
\text { kelompok } \\
\text { - siswa mampu } \\
\text { memprediksi dengan } \\
\text { benar } \\
\text { - siswa mencocokan hasil } \\
\text { prediksi dengan bacaan } \\
\text { - Penyampaian materi } \\
\text { kepada siswa sesuai } \\
\text { dengan scenario } \\
\text { pembelajaran } \\
\text { - Siswa membaca diam } \\
\text { sambil memahami bacaan } \\
\text { selanjutnya mencocokan } \\
\text { prediksi mereka. } \\
\text { - Menjawab pertannyaan } \\
\text { bacaan } \\
\text { - Pembahasan hasil belajar } \\
\text { siswa serta membuat } \\
\text { kesimpulan materi } \\
\text { - Post test } \\
\text { - Hasil test }\end{array}$ \\
\hline Pengamatan & $\begin{array}{l}\text { 1) } \\
\text { 2) } \\
\text { 3) }\end{array}$ & $\begin{array}{l}\text { Kegiatan Belajar Mengajar } \\
\text { Keaktifan siswa dalam diskusi kelompok. } \\
\text { Keaktifan siswa dalam proses memahami bacaan. } \\
\text { Kemampuan siswa dalam mengekspresikan prediksi dan } \\
\text { pemahaman mereka tentang bacaan tersebut di dalam } \\
\text { bahasa inggris. Adapun intrument yang digunakan } \\
\text { peneliti dalam pengamatan yaitu berupa hasil kuis, } \\
\text { lembar observasi dan catatan lapangan. }\end{array}$ & $\begin{array}{l}\text { - Hasil Belajar atau data } \\
\text { yang akan dianalisis untuk } \\
\text { refleksi. } \\
\text { - Keaktifan Siswa. }\end{array}$ \\
\hline
\end{tabular}




\section{Teknik Analisis Data}

Analisis data dalam penelitian tindakan ini diwujudkan dengan menggunakan analisis data deskriptif yang terdiri dari rencana kegiatan pembelajaran, pelaksanaan tindakan, hasil kegiatan pembelajaran dan data hasil observasi pada pelaksanaan pembelajaran. Sedangkan untuk kegunaan berupa kemajuan prestasi belajar pemahaman bacaan Bahasa Inggris digunakan data kuantitatif.

Data kuantitatif ini dianalisis dengan menggunakan statistik deskriptif beruji mean, prosentase yang dapat ditampilkan melalui table 2 , grafik yang diinterprestasi dengan deskriptif kualitatif.

Tabel 2. Kategori Tingkat Penguasaan
\begin{tabular}{ccc}
\hline No & $\begin{array}{c}\text { Tingkat } \\
\text { Penguasaan }\end{array}$ & Kategori \\
\hline $\mathbf{1}$ & $\geq 81$ & Sangat Baik \\
\hline $\mathbf{2}$ & $76-80$ & Baik \\
\hline $\mathbf{3}$ & $70-75$ & Sedang \\
\hline $\mathbf{4}$ & $66-69$ & Rendah \\
\hline $\mathbf{5}$ & $\leq 65$ & Sangat Rendah \\
\hline
\end{tabular}

Untuk analisis data kuantitatif yang diperoleh dari hasil tes siswa maka dapat dilihat sebagai berikut :

$\frac{\text { Skor }}{\text { Jumlah jawaban benar }} \times 100$

Rentang Nilai :

$\mathrm{A}=\geq 81$ = Sangat Baik (dapat memahami dan dapat menjawab pertanyaan bacaan dengan benar)

$\mathrm{B}=76-80=$ Baik (dapat memahami dan dapat menjawab pertanyaan bacaan dengan berterima)

$\mathrm{C}=70-79=($ Sedang (cukup memahami dan dapat menjawab pertanyaan bacaan dengan berterima)

$\mathrm{D}=66-69=$ Rendah (kurang dapat memahami dan menjawab pertanyaan dengan berterima)

$\mathrm{E}=\leq 65=$ Sangat Rendah (tidak dapat memahami dan tidak dapat menjawab pertanyaan bacaan dengan berterima)

\section{Indikator Keberhasilan}

Indikator keberhasilan penelitian ini adalah peningkatan keterampilan memahami bacaan dalam bahasa inggris yang ditunjukkan dengan ciri - ciri para siswa menunjukkan interaksi yang aktif, keterlibatan siswa dalam berbagai kegiatan, sikap siswa yang antusias dan senang dalam belajar serta kepercayaan diri siswa yang meningkat dan peningkatan kemampuan memahami bacaan yang dilihat dari faktor kemampuan siswa mengekspresikan pengetahuan melalui kebahasannya. Tindakan Penelitian ini akan dihentikan apabila 70 persen siswa di kelas tersebut mendapatkan nilai $\geq 70$ dan telah menunjukkan keaktifan dan kemampuan memahami bacaan yang baik.

\section{HASIL PENELITIAN}

\section{Analisis Data Hasil Tindakan}

1. Perhitungan Data Pencapaian Hasil PreTest Kemampuan Memahami Bacaan.

Peneliti bersama guru mitra diawal penelitian membuat perencanaan dalam melaksanakan penelitian tindakan tentang pemahaman bacaan pada pembelajaran reading siswa kelas XI IPA. Sebagai langkah awal, siswa diberikan tes awal (pre-test) untuk melihat kemampuan awal mereka. Dari hasil tes diperoleh nilai keseluruhan siswa adalah 2373 dengan nilai rata-rata adalah 65,92

Perolehan rata - rata ini masih rendah dari nilai ketuntasan yang diharapkan adalah $\geq$ 70. Nilai tertinggi yang diperoleh siswa adalah 80 oleh 2 orang siswa, sementara nilai terendah yang diperoleh siswa adalah 40. Atau kalau dilihat dari persentase hasil belajar siswa dapat disimpulkan bahwa 63, $89 \%$ (23 orang) siswa belum memenuhi standar nilai $\geq 70$. Hanya 13 orang siswa atau $36,11 \%$ yang telah mencapai standar ketuntasan penguasaan pemahaman bacaan.

Analisis kuantitatif hasil pre-tes siswa dapat dilihat pada Tabel 3 dibawah ini.

\section{Tabel 3. Hasil Pre-Test}

\begin{tabular}{lccc}
\hline No & Kategori & $\begin{array}{c}\text { Jumlah } \\
\text { Siswa }\end{array}$ & \% \\
\hline $\mathbf{1}$ & Sangat baik $(\geq 81)$ & - & - \\
\hline $\mathbf{2}$ & Baik $(76-80)$ & 5 & 13,89 \\
\hline $\mathbf{3}$ & Sedang $(70-75)$ & 8 & 22,23 \\
$\mathbf{4}$ & Rendah $(66-69)$ & 5 & 13,89 \\
\hline $\mathbf{5}$ & Sangat rendah $(\leq-$ & 18 & 50 \\
& $65)$ & & \\
\hline
\end{tabular}

Jumlah 100

Tingkat pencapaian pada pre - test ini dapat dikatakan bahwa tingkat penguasaan pemahaman bacaan yang dimiliki siswa kelas XI IPA 1 masih rendah, yaitu $36,11 \%$ atau hanya 13 siswa dari 36 jumlah siswa yang memperoleh nilai $\geq 70$. 
Hasil belajar siswa setelah diberikan tindakan pada siklus I mengalami peningkatan dengan perolehan nilai rata - rata 72, 19. Hasil ini lebih baik dari pre-test. Namun belum mencapai indikator ketuntasan yang telah ditetapkan, hanya 22 orang siswa atau $61,11 \%$ dari total jumlah siswa dinyatakan telah mencapai nilai $\geq 70$. Hasil ini masih dinyatakan kurang, oleh karena itu perlu dilakukan peningkatan dan perbaikan agar hasil ini didapat benar - benar mencapai target yang telah ditentukan.

Analisis kuantitatif hasil belajar siswa dari siklus pertama dapat dilihat pada Tabel 4 . di bawah ini.

\section{Tabel 4. Analisis Observasi Kemampuan} Memahami Bacaan Siklus I

\begin{tabular}{|c|c|c|c|}
\hline No & Kategori & $\begin{array}{l}\text { Jumlah } \\
\text { Siswa }\end{array}$ & $\%$ \\
\hline 1 & Sangat baik $(\geq 81)$ & 6 & 16,66 \\
\hline 2 & Baik (76-80) & 7 & 19,44 \\
\hline 3 & Sedang (70-75) & 9 & 25 \\
\hline 4 & Rendah (66-69) & 10 & 27,77 \\
\hline 5 & Sangat rendah $(\leq 65)$ & 4 & 11,11 \\
\hline & Jumlah & 36 & 100 \\
\hline
\end{tabular}

Dari Tabel 4 di atas dapat dilihat dari 36 siswa terdapat 6 siswa yang sangat baik, 7 siswa yang memperoleh predikat baik, 9 siswa berpredikat sedang. Dan terdapat 10 orang berpredikat rendah serta 4 siswa yang berpredikat sangat rendah. Dari tabel 4.2 dapat disimpulkan terdapat $61,11 \%$ siswa yang memperoleh nilai $\geq 70$.

Berdasarkan hasil pembelajaran yang diharapkan dengan penarapan strategi DRTA ternyata menghasilkan nilai yang diharapkan jika dibandingkan dengan hasil belajar pretest,walaupun belum mencapai nilai standar atau KKM yang ditetapkan $\geq 70$.

Berdasarkan data yang diperoleh pada siklus pertama dan kendala yang ditemui di kelas maka peneliti dan observer melakukan diskusi dan memutuskan untuk melanjutkan tindakan pada siklus kedua. Pelaksanaan siklus kedua ini difokuskan untuk meningkatkan hasil tindakan dengan memperbaiki pelaksanaan tindakan yang menjadi kendala pada siklus pertama.

Adapun alasan peneliti melanjutkan tindakan ini ke siklus kedua disebabkan oleh kendala yang dihadapi selama berlangsungnya tindakan antara lain : (1) siswa masih merasa asing dengan situasi belajar yang berbeda dari biasanya. (2) masih ada siswa yang merasa enggan untuk membaca apalagi bacaan yang disebabkan oleh ketidak mampuan mereka memahami/mengerti kata - kata yang pada bacaan/teks. (3) pengggunaan waktu belum sepenuhnya efektif. (4) minat siswa masih belum terlihat begitu antusias.

Setelah dilakukan tindakan perbaikan pada siklus II ini, berdasarkan observasi yang dilakukan oleh guru mitra (observer), maka untuk kemampuan memahami bacaan siswa dari 36 siswa terdapat $10 \quad(27,77 \%)$ yang memperoleh predikat sangat baik, $12(33,33 \%)$ dengan predikat baik dan $9(25 \%)$ siswa dengan predikat sedang. Sehingga jika berdasarkan persentase total maka 36 siswa terdapat $86,11 \%$ siswa yang telah mencapai nilai $\geq 70$.

Berdasarkan data tersebut maka penelitian ini dinyatakan telah mencapai indikator keberhasilan tindakan yaitu jika siswa memperoleh nilai kemampuan memahami bacaan $\geq 70$. Untuk lebih jelas hal ini dapat dilihat pada Tabel 5. berikut.

Tabel 5. Analisis Observasi Kemampuan
Memahami Bacaan Siklus II
\begin{tabular}{|lccc}
\hline No & Kategori & $\begin{array}{c}\text { Jumlah } \\
\text { Siswa }\end{array}$ & \% \\
\hline $\mathbf{1}$ & Sangat baik $(\geq 81)$ & 10 & 27,77 \\
\hline $\mathbf{2}$ & Baik $(76-80)$ & 12 & 33,33 \\
\hline $\mathbf{3}$ & Sedang $(70-75)$ & 9 & 25,00 \\
\hline $\mathbf{4}$ & Rendah $(66-69)$ & 3 & 8,33 \\
\hline $\mathbf{5}$ & Sangat Rendah $(\leq 65)$ & 2 & 5,55 \\
\hline & Jumlah & $\mathbf{3 6}$ & $\mathbf{1 0 0}$ \\
\hline
\end{tabular}

Berdasarkan data pada Tabel 5 di atas terdapat peningkatan kemampuan memahami bacaan siswa. Dari 36 siswa terdapat 10 siswa berpredikat sangat baik, 12 siswa berpredikat baik, 9 siswa berpredikat sedang. Dan hanya 3 siswa berpredikat rendah serta 2 siswa yang berpredikat sangat rendah. Pada siklus kedua ini total siswa yang memperoleh nilai $\geq 70$ berkisar $86,11 \%$. Berdasarkan data tersebut maka indikator keberhasilan tindakan telah tercapai.

Untuk lebih jelasnya hasil yang diperoleh pada siklus II dapat dilihat pada gambar 3 di bawah ini.

\section{SIKLUS II}

Pada diagram batang tersebut dapat dilihat kemampuan memahami bacaan siswa pada siklus II. Untuk ketegori nilai sangat baik, 
baik dan sedang, siklus kedua lebih tinggi dari pada siklus pertama sedangkan untuk ketegori penilaian rendah dan sangat rendah, siklus kedua lebih rendah dari pada siklus pertama. Hal ini menunjukkan kemajuan yang diperoleh siswa pada siklus kedua melebihi siklus pertama.

\section{Perhitungan Data Peningkatan Keaktifan Siswa Siklus I dan Siklus II}

Begitu juga halnya dengan siswa yang aktif mengalami peningkatan pada siklus I. dari 36 siswa terdapat 24 siswa yang aktif atau sekitar $66,66 \%$ siswa yang aktif dari nilai ketuntasan keaktifan yaitu $\geq 70$. Adapun hasil nilai keaktifan siswa dapat dilihat pada Tabel 6 berikut.

Tabel 6. Analisis Observasi Keaktifan Siklus I

\begin{tabular}{lccc}
\hline No & Kategori & $\begin{array}{c}\text { Jumlah } \\
\text { Siswa }\end{array}$ & \% \\
\hline $\mathbf{1}$ & Sangat Baik & 2 & 5,55 \\
\hline $\mathbf{2}$ & Baik & 6 & 16,66 \\
\hline $\mathbf{3}$ & Sedang & 16 & 44,44 \\
\hline $\mathbf{4}$ & Rendah & 8 & 22,22 \\
\hline $\mathbf{5}$ & Sangat Rendah & 4 & 11,11 \\
\hline & Jumlah & $\mathbf{3 6}$ & $\mathbf{1 0 0}$ \\
\hline
\end{tabular}

Dari Tabel 6 di atas dapat dilihat dari 36 siswa terdapat 2 siswa yang memperoleh predikat sangat baik, 6 siswa yang memperoleh predikat baik,16 siswa berpredikat sedang. Dan terdapat 8 siswa berpredikat rendah serta 4 siswa berpredikat sangat rendah. Dari tabel ini dapat disimpulkan terdapat $66,66 \%$ siswa yang aktif.

Tingkat keaktifan siswa, siswa terlihat cukup aktif dan komunikatif dalam merespon pembelajaran. Namun berdasarkan temuan nilai yang terdapat antara pemahaman bacaan yaitu 78 dan nilai keaktifan yaitu 75 berarti ada siswa yang agak pendiam sehingga kelihatan kurang aktif sementara tingkat pemahamannya cukup tinggi, sementara ada siswa yang tingkat pemahamannya rendah yaitu 68 tapi tingkat keaktifannya cukup tinggi yaitu 72 .

Selanjutnya tingkat keaktifan siswa juga mengalami peningkatan dari siklus sebelumnya yaitu 36 siswa terdapat $8(22,22 \%)$ siswa yang berpredikat sangat baik, $17(47,22$ $\%)$ siswa berpredikat baik dan 8 (22,22 \%) siswa berpredikat sedang. Secara keseluruhan total siswa yang aktif pada siklus kedua ini yaitu $91,66 \%$.Keatifan siswa dapat dilihat pada Tabel 7.

\begin{tabular}{|c|c|c|c|}
\hline No & Kategori & $\begin{array}{c}\text { Jumlah } \\
\text { Siswa }\end{array}$ & $\%$ \\
\hline 1 & Sangat Baik & 8 & 22,22 \\
\hline 2 & Baik & 17 & 47,22 \\
\hline 3 & Sedang & 8 & 22,22 \\
\hline 4 & Rendah & 2 & 5,55 \\
\hline 5 & $\begin{array}{l}\text { Sangat } \\
\text { Rendah }\end{array}$ & 1 & 2,77 \\
\hline & Jumlah & 36 & 100 \\
\hline
\end{tabular}

Dari Tabel 7 di atas dapat dilihat dari 36 siswa terdapat 8 siswa yang memperoleh predikat sangat baik, 17 siswa yang memperoleh predikat baik, 8 siswa berpredikat sedang. Dan terdapat 2 siswa yang berepredikat rendah serta 1 siswa yang berpredikat sangat rendah. Dari tabel ini dapat disimpulkan terdapat 91, $66 \%$ siswa yang aktif. Untuk lebih jelasnya peningkatan keaktifan siswa pada siklus II dapat dilihat pada gambar 5 berikut.

\section{SIKLUS II}

Pada diagram batang tersebut dapat dilihat peningkatan keaktifan siswa pada siklus kedua jika dibandingkan siklus pertama. Untuk kategori penilaian sangat baik, baik dan sedang siklus kedua lebih tinggi dari pada siklus pertama. Sedangkan untuk kategori sangat rendah, siklus kedua lebih rendah dari pada siklus pertama.

Terdapat peningkatan terhadap hasil belajar siswa. Dapat dijelaskan bahwa siswa yang memperoleh nilai $\geq 70$ adalah $86,11 \%$ dari total jumlah siswa seluruhnya. Hal ini berarti telah mencapai kesuksesan sesuai indikator, yaitu siswa dikatakan sukses dalam pembelajaran jika siswa tersebut memperoleh nilai minimal 70 dan tindakan akan dihentikan jika minimal $80 \%$ siswa dalam kelas telah memperoleh nilai $\geq 70$. Berdasarkan indikator tersebut, maka peneliti dan observer memutuskan untuk tidak melanjutkan tindakan pada siklus berikutnya.

Pada siklus II ini, berdasarkan hasil pembelajaran yang diharapkan dengan penerapan strategi DRTA ternyata menghasilkan nilai yang lebih memuaskan jika dibandingkan dengan hasil belajar pada siklus I, yang telah mencapai nilai standard atau KKM yang ditetapkan $\geq 70$ demikian juga dengan tingkat 
keaktifan siswa, siswa terlihat cukup aktif dan komunikatif dalam merespon pembelajaran. Namun berdasarkan temuan pada siklus II, nilai terdapat antara pemahaman bacaan yaitu 72 dan nilai keaktifan yaitu 68 berarti ada siswa yang agak pendiam sehingga kelihatan kurang aktif sementara tingkat pemahamannya cukup tinggi, sementara ada siswa yang tingkat pemahamannya rendah yaitu 69 tapi tingkat keaktifannya cukup tinggi yaitu 74 .

Peningkatan penguasaan pemahaman bacaan bahasa inggris siswa mulai dari pelaksanaan Pre-Test hingga dilaksanakan tindakan dan diakhiri dengan tes akhir pada setiap siklus I dan siklus II, maka dapat dijelaskan bahwa tingkat ketuntasan semua adalah $86,11 \%$ atau sebanyak 31 siswa telah tuntas dalam pembelajaran pemahaman bacaan melalui strategi DRTA (DRTA), dan hasil peningakatan ini lebih jelasnya dapat dilihat pada Tabel 8 dan Gambar 6 berikut.

Tabel 8. Selama Siklus Tindakan

\begin{tabular}{lccc}
\hline No & Kategori & $\begin{array}{c}\text { Jumlah } \\
\text { Siswa }\end{array}$ & Persentase \\
\hline $\mathbf{1}$ & Pre-Test & 13 & 36 \\
\hline $\mathbf{2}$ & Siklus I & 22 & 61 \\
\hline $\mathbf{3}$ & Siklus II & 31 & 86 \\
\hline
\end{tabular}

\section{PEMBAHASAN}

Dari hasil yang telah diuraikan pada tiap siklus di atas, nyata bahwa pembelajaran pemahaman bacaan dengan menggunakan strategi DRTA dapat meningkatkan pemahaman bacaan bagi siswa. Strategi pembelajaran DRTA bermanfaat bagi siswa sebagai salah satu strategi pembelajaran pemahaman bacaan yang sangat tepat dan menarik bagi siswa karena strategi ini sangat menarik minat dan perhatian siswa ketika siswa dituntut aktif dalam kegiatan memprediksi judul/gambar yang ditunjuk oleh guru yang dapat diungkapkan melalui kalimat atau kata. Setelah itu siswa diarahkan ke aktifitas membaca diam teks bacaan sambil mencocokkan hasil prediksi mereka dengan teks yang mereka baca. Dalam aktifitas ini kegiatan Scanning dilakukan oleh siswa. Selanjutnya ketika siswa diberi pertanyaan bacaan maka siswa melakukan kegiatan membaca secara Scanning dan skimming.

Hakikat pemahaman sendiri menurut Thorndike sebagaimana disitasi oleh McNeil (1992:16), pemahaman berorientasi proses yang melibatkan aktivitas mental membaca ketika berinteraksi dengan teks tertulis, pengukuran dilakukan dengan meminta pembaca menjawab pertanyaan bacaan. Dengan kata lain memahami bacaan dapat didefinisikan sebagai kemampuan menjawab pertanyaan pemahaman yang sesuai.

Hal ini dikuatkan oleh penelitian Melvita, Santi (2009) dalam penelitiannya mengenai pengaruh strategi pembelajaran dan gaya belajar terhadap hasil belajar bahasa inggris siswa SMA di Kota Banda Aceh menunjukkan bahwa siswa yang diajar dengan menggunakan strategi DRTA memiliki hasil belajar yang lebih tinggi dibandingkan dengan siswa yang diajar dengan strategi Known-WantI earned (KWL).

Sedangkan gambaran mengenai keaktifan siswa terhadap pembelajaran dengan menggunakan strategi DRTA, berdasarkan hasil pengamatan yang dilakukan oleh guru mitra (observer) maka proses pembelajaran baik pada siklus I dan Siklus II, terutama pada siklus II mengalami peningkatan keaktifan yang signifikan. Keaktifan dan kemampuan memahami teks sudah betambah dan tidak kaku lagi hal ini terlihat dari ketidak canggungan mereka dalam mengekpresikan hasil prediksi mereka. Hal ini sesuai dengan yang ditemukan oleh Slavin (1995), mengemukakan bahwa siswa akan lebih aktif menemukan dan memahami konsep yang sulit apabila mereka dapat mendiskusikan dengan temannya.

Berdasarkan hasil observasi nilai hasil belajar yaitu nilai pemahaman bacaan dan nilai keaktifan siswa dapat disimpulkan sebagai berikut :

1. Strategi pembelajaran DRTA sangat bermanfaat bagi siswa dalam meningkatkan ketertarikan dan keaktifan siswa dalam pembelajaran pemahaman bacaan, ini ditunjukkan dari hasil pencapaian hasil belajar siswa yang tinggi.

2. Berdasarkan hipotesis strategi pembelajaran DRTA bahwa jika tingkat keaktifan siswa tinggi maka tingkat pemahaman siswa pun akan tinggi, atau jika tingkat pemahaman bacaan siswa tinggi otomatis tingkat keaktifan siswa pun menjadi tinggi. Namun berdasarkan temuan peneliti di lapangan bahwa hal ini sepenuhnya tidak tepat oleh karena ketrampilan yang diuji cobakan adalah ketrampilan memahami bacaan. Mungkin saja siswa yang agak pendiam tapi tingkat pemahamannya tinggi terhadap bacaan sehingga siswa tersebut dapat memahami 
dan menjawab pertanyaan bacaan atau test dengan hasil yang memuaskan, sementara ada siswa yang tingkat keaktifannya tinggi namun tingkat pemahaman bacaannya rendah.

3. Motivasi siswa dalam pembelajaran bahasa inggris setelah menggunakan strategi pembelajaran DRTA adalah tinggi.

4. Program tindakan kelas yang dilakukan kepada siswa sangat perlu untuk meningkatkan hasil belajar siswa dan keaktifan dalam belajar.

\section{PENUTUP}

Pertama, maka kegiatan pembelajaran bahasa inggris diterapkan dengan strategi pembelajaran DRTA dan telah berhasil meningkatkan keaktifan siswa dalam belajar. Hal ini diketahui berdasarkan data observasi yang menunjukkan peningkatan keaktifan siswa selama siklus tindakan langsung. Pada siklus pertama terdapat $66,66 \%$ siswa yang aktif selama proses pembelajaran berlangsung. Selanjutnya jumlah ini meningkat pada siklus kedua menjadi 91,66 \% siswa yang aktif di kelas. Data tersebut membuktikan bahwa pembelajaran bahasa inggris dengan penerapan strategi pembelajaran DRTA dapat memicu semangat dan minat siswa untuk aktif dalam mengikuti pelajaran terutama dalam ketrampilan membaca di kelas.

Kedua, kegiatan pembelajaran bahasa inggris dengan menerapkan strategi pemahaman bacaan DRTA dapat meningkatkan kemampuan memahami bacaan pada siswa. Hal ini berdasarkan data yang menunjukkan peningkatan kemampuan memahami bacaan siswa sebelum dan sesudah tindakan. Berdasarkan pre - test sebelum tindakan terdapat $36,11 \%$ siswa memiliki kemampuan memahami bacaan $\geq 70$. Setelah dilaksanakan tindakan maka terjadi peningkatan yaitu pada siklus pertama terdapat $61,11 \%$ siswa yang memperoleh nilai $\geq 70$. Namun karena persentase tersebut belum memenuhi indikator keberhasilan tindakan maka dilakukan siklus kedua. Setelah siklus kedua dilaksanakan maka terjadi peningkatan kemampuan memahami bacaan siswa menjadi $86,11 \%$ siswa yang memperoleh nilai $\geq 70$.

\section{DAFTAR PUSTAKA}

Dick W. L. Carey \& carey J.O., (2005). The Systematic design of Instruction $6^{\text {th }}$ Edition. Florida: Pearson

Dimyanti, M. (1995). Penelitian Kualitatif untuk Ilmu-ilmu Sosial. Malang : PPS IKIP Malang

Forum komunikasi Mahasiswa Pascasarjana Teknologi Pendidikan UNJ

Gagne, R.M. (ed). (1987). Instructional Tecnology : Foundation. London: LEA Publisher

Gagne, R.M \& Briggs J.L, (1988). Principles of Instruction Design. New York : Holt, Rinehalt and Winston

Gagne, R.M \& Briggs L.J \& Wagger, W.W. (1992). Principles of Instructional Desain. New York: Holt, Rinehalt and Winston

Hamalik, O. (2005). Perencanaan Pengajaran Berdasarkan Pendekatan Sistem. Jakarta : Bumi Aksara

Miarso, Y. (2004). Menyemai Benih Teknologi Pendidikan. Jakarta : Kencana

Oxford, R.I. (1990). Language Learning Strategies; What Every teacher Should know. United State of America: Heinle dan Heinle.

Prawiradilaga, Salma, D \& Siregar, E. (2008). Mosaik Tegnologi pendidikan. Jakarta : Kencana

Sanjaya, W. (2005). Pembelajaran Dalam Emplementasi Kurikulum Berbasis Kompetensi. Jakarta : Kencana Prenada Media.

Sardiman, (2009). Interaksi dan Motivasi Belajar Mengajar. Jakarta: Raja Grafindo Persada

Soedarso. (2004). Speed Reading. System membaca Cepat dan Efektif. Jakarta : Gramedia Pustaka Umum. 